\title{
Makarenko $D$ INVESTIGATION OF THE RESPONSE SURFACES DESCRIBING THE MATHEMATICAL MODEL OF THE INFLUENCE OF TEMPERATURE AND BEO CONTENT IN THE COMPOSITE MATERIALS ON THE YIELD AND ULTIMATE STRENGTH
}

\begin{abstract}
Методом рідж-аналізу проведено дослідження поверхонь відгуку, що описують математичні моделі впливу температури та вмісту ВеО на границі міцності та плинності композитних матеріалів, що використовуються, зокрема, при виробництві авіаційної техніки. Показано, що на основі математичної моделі, яка побудована шляхом реалізації центрального ортогонального композиційного плану (ОЦКП) другого порядку, можуть бути знайдені субоптимальні значення технологічних режимів. Ці режими забезпечують отримання оптимальних значень границь плинності та міцності композиційного сплаву на основі берилію з урахуванням обмежень, що накладаються на технологічний процес.
\end{abstract}

Ключові слова: рідж-аналіз, субоптимальні значення, композиційний матеріал, оксид берилію, граниия плинності, граниия міцності, поверхня відгуку.

\section{Introduction}

Any modern structure includes parts that combine various materials and metal alloys. Owing to this combination, it is often possible to increase the reliability of the structure as a whole and to optimize the performance parameters of its component nodes. So, one of the types of used materials are composite materials, which allow to ensure maximum performance characteristics with minimal weight of the structure.

In this work, the dispersion-strengthened berylliumbased composite materials are considered, which are widely used in many branches of the economy, for example, for the production of details of the designs of gliders of aircraft and helicopters, power units of some types of cars (including sports) and so on [1]. Most often, Al-Be systems are used for dispersion-strengthened composite materials (DSCM), because such alloys combine high plasticity of aluminum and strength properties of beryllium [2-6].

The most effective beryllium hardeners are $\mathrm{BeO}$ oxide and $\mathrm{Be}_{2} \mathrm{C}$ carbide. The standard volume fraction of $\mathrm{BeO}$ is from 0.8 to $3 \%$. Investigations [7] found that the time resistance of the $\mathrm{Be}-\mathrm{BeO} \mathrm{DSCM}$ increases with the oxide content, while the strengthening efficiency increases with increasing temperature. The creep resistance and the longterm strength of $\mathrm{Be}-\mathrm{BeO}$ composite materials at elevated temperatures are relatively small [3]. The use of beryllium carbide $\mathrm{Be}_{2} \mathrm{C}$ as a strengthening phase makes it possible to increase the $100-\mathrm{hr}$ beryllium strength at $650{ }^{\circ} \mathrm{C} 3$ times, and at $730{ }^{\circ} \mathrm{C}$ is more than 5 times.

By this time, the task of determining the berylliumbased DSCM parameters and modeling their properties for quality management during the creation, operation and disposal was not fully reflected in the studies. The study of the beryllium-based DSCM parameters will make it possible to single out their main significant parameters, to assess the starting point from which values of the studied parameters will have a significant impact on the requirements for such materials. This, in turn, will optimize the composition of these materials in terms of both operation and subsequent disposal.

\section{The object of research and its technological audit}

The object of research is the dependence of mechanical properties (yield strength and ultimate strength) on the beryllium-based DSCM on the parameters of their operation (temperature regime) and $\mathrm{BeO}$ content in the composition of the material. Such dependence can be established on the basis of technological audit of the process, which has the ultimate aim of constructing an analytical description based on the results of production experimental data, for example, in the form of regression equations. Taking into account that the description and investigation of the stationary region is of the greatest interest, it is necessary to choose the appropriate mathematical apparatus of investigation, which makes it possible to identify the presence of local extremes providing maximum values of the output variable, taking into account the constraints imposed by the conditions of the technological process. In this way, in particular, ridge analysis can be chosen. This method allows analyzing the received response surfaces and determining not only the tendency of the dependences of the material properties on the operation parameters and the characteristics of the material itself, but also to more accurately estimate the optimum values. The latter 
is particularly advantageous from the point of view of optimizing the operation parameters of structures made from these materials, and also from the point of view of the process of their subsequent disposal.

\section{The aim and objectives of research}

The aim of research is determination the suboptimal values of technological regimes ensuring the optimal values of the yield strength and ultimate strength of a berylliumbased composite alloy, taking into account the limitations imposed on the technological process.

To achieve the aim, the following tasks are accomplished:

1. To conduct a ridge analysis of the response surface, which describes the influence of temperature and $\mathrm{BeO}$ content in composite materials on the yield strength and ultimate strength of DSCM.

2. Obtaining qualitative decisions regarding the nature of the influence of technological regimes on the yield strength and ultimate strength of these materials.

\section{Research of existing solutions of the problem}

There are several ways to investigation of the properties of materials, which can be conditionally divided into:

1) analytical (use of various mathematical models, obtained on the basis of experimental data);

2) experimental (the use of various physical methods for investigation of the properties of materials).

Both types of research have their own advantages and disadvantages. Thus, experimental studies allow obtaining fairly accurate results, but they are labor-intensive and material-intensive. While analytical methods allow one to obtain results within a broader range that can't be achieved by experimental research. However, the disadvantage of these methods is that they are based on experimental values, which makes their application dependent on the accuracy of the performed experiments.

Various methods are used for the investigation of beryllium-based DSCM. Thus, in $[8,9]$ the properties of materials are investigated, in particular, on the basis of X-ray diffraction, which makes it possible to reveal differences in the density of materials and to determine their properties depending on the loads of various types.

In [10-12], materials are investigated by the ab initio method, which although it is one of the most used, but does not always allow achieving accurate results, since it requires experimental verification.

In [13], first-principles calculations based on the functional density theory are used to study the properties of materials.

In [14], to investigate the properties of materials, optically stimulated luminescence is used, which makes it possible to detect differences in the density of the material.

In [15], combined X-ray and optically stimulated luminescence methods are used for research.

In [16], in addition to the effect of X-ray radiation, the characteristics of the secondary yield of the alloy electrons are also used for investigations.

In [17], the isothermal decay method is used to determine the activation energy of the material.

In [18], beryllium-based DSCM is studied by the method of constructing response surfaces using the central orthogonal composite plan.
Thus, the analysis of literature data shows that basically the properties of beryllium-based DSCM are carried out experimentally, and analytically they are not fully carried out, which makes the study relevant.

\section{Methods of research}

The mathematical models obtained in [18] are taken as a starting material:

$$
\begin{aligned}
& y_{1}=201,523+29,1725 x_{1}-41,675 x_{2}- \\
& -11,975 x_{1} x_{2}-9,475 x_{1}^{2}+2,5 x_{2}^{2}, \\
& y_{2}=265,3665+34,1735 x_{1}-40,008 x_{2}+ \\
& +23,475 x_{1} x_{2}-19,025 x_{1}^{2}+8,75 x_{2}^{2},
\end{aligned}
$$

where $x_{1}, x_{2}$ - the values of the input variables in the normalized form, associated with the natural values by the implementation of the procedure, which is given in [18].

The obtained mathematical models describe a certain response surface in the factor space $\ll \mathrm{BeO}$ content - test temperature», which should be analyzed to find the optimal values of technological parameters. As such parameters - the essence of input variables - $\mathrm{BeO}$ content in the composite material, $\%\left(x_{1}\right)$ and temperature, ${ }^{\circ} \mathrm{C}\left(x_{2}\right)$ are chosen. The yield strength, $\operatorname{MPa}\left(y_{1}\right)$ and ultimate strength, MPa $\left(y_{2}\right)$ are chosen as output variables.

The application of the solutions obtained in this way can be used to optimize the use of beryllium-based composite materials.

The graphic image of the response surface can be represented in accordance with the principles, which is given in [19]. To find the optimal technological regimes - the $\mathrm{BeO}$ content and the temperature - using the criterion of maximum of yield and ultimate strength limits, one can use the methods of comb analysis of the response surface described in [20]. And this, in turn, involves solving two problems: constructing a mathematical model of the «composition-property» type and analyzing the resulting model for the purpose of analytical description of the response surface. If the first of these problems can be solved on the basis of artificial orthogonalization methods [21, 22], then it is proposed to use the ridge-analysis procedure to solve the second one. The latter allows to calculate the suboptimal values of the parameters $x_{i}$ for all output variables for which the composition-property type regression equations are constructed, and to determine the admissible ranges of the input variables $x_{i}$, which satisfy the requirements at once for several output variables. That is, it is about compromise optimization.

The solution of the optimization problem in parametric form looks like this:

$$
\left\{\begin{array}{l}
x^{*}(\lambda)=(\lambda I-A)^{-1} a, \\
r(\lambda)=\sqrt{x^{* \prime} x^{*},} \\
y^{*}(\lambda)=a_{0}+2 a^{\prime} x^{*}+x^{* \prime} A x^{*},
\end{array}\right.
$$

where $a_{0}, a, A$ - the coefficients of the model (1); $\lambda$ - the eigenvalues of the matrix $A ; x^{*}(\lambda)$ - the optimal values of the input variables; $r(\lambda)$ - the radius of the cylinder 
introduced to find the boundary conditions and determine the position of the optimal point with coordinates $\left(x_{1}^{*}, x_{2}^{*}\right)$ at the specified boundary of the factor space given by the second equation of parametric description $(3) ; y^{*}(\lambda)-$ optimal values of output variables (yield strength and ultimate strength, $\mathrm{MPa}$ ).

\section{Research results}

6.1. Results of investigation of response surfaces describing the mathematical model of the effect of temperature and BeO content in composite materials on the yield strength. Fig. 1 shows The graph of the dependence $r(\lambda)$ for the range of eigenvalues $[-30 ; 30]$, and in Fig. $2-$ dependence of the output variable on the radius of the cylinder introduced to find the boundary conditions and determine the position of the optimal point with the coordinates $\left(x_{1}^{*}, x_{2}^{*}\right)$ on the indicated boundary of the factor space.

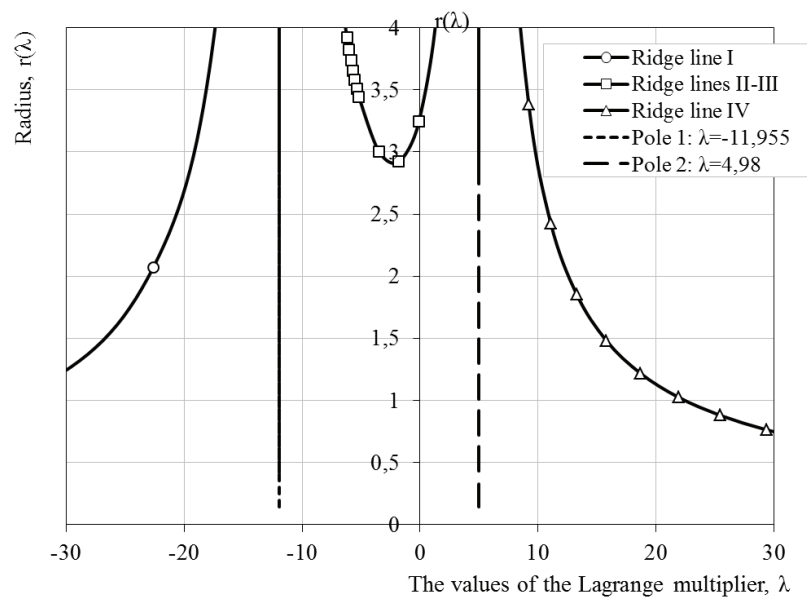

Fig. 1. The graph of the dependence $r(\lambda)$ for the range of eigenvalues $[-30 ; 30]$

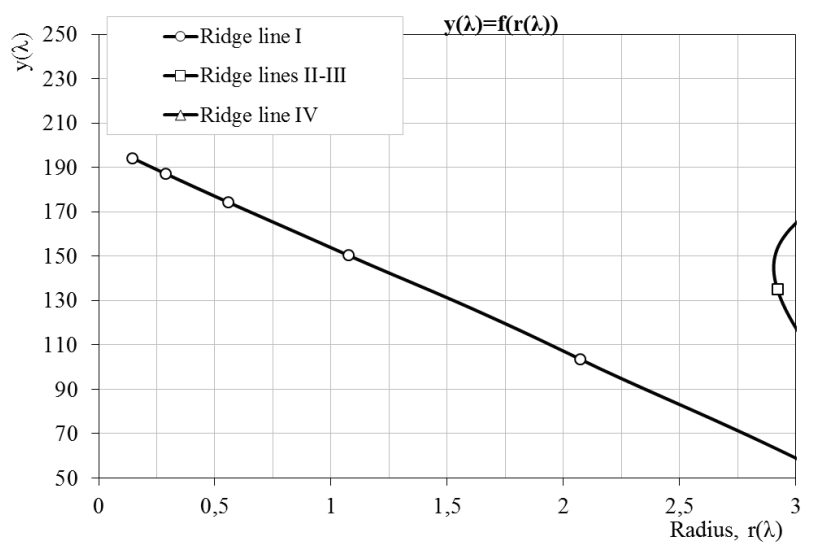

Fig. 2. Dependence of the output variable $y_{1}^{*}(\lambda)$ for the range limited by the selected experiment plan

The resulting graphs make it possible to determine the suboptimal values of the input variables at the boundaries of the planning area, providing a maximum with allowance for the limits of the yield strength.

The solution of the equation $|A-\lambda I=0|$ determines two values of the eigenvalues $\lambda$ in the range $-\infty<\lambda<+\infty$, ensuring the optimal values of the output variable, namely: $\lambda_{1}=-11.955, \lambda_{2}=4.98$ (Fig. 1). This means that in the considered range only solutions related to the ridge line I is meaningful. Investigation of the character of the function $(\lambda)$ in the considered range makes it possible to find the optimal values of the output variable and the values of the input variables providing it at the boundary of the investigated planning area.

Fig. 2 shows that the optimum values of the yield strength are achieved in the range from 130 to $200 \mathrm{MPa}$. After analyzing Fig. 3, it is possible to obtain a set of suboptimal values of the input variables providing optimal values of the yield strength. For example, such values are: $t=456{ }^{\circ} \mathrm{C}$ with $\mathrm{BeO}$ content of $1.35 \%$ and $t=528{ }^{\circ} \mathrm{C}$ with $\mathrm{BeO}$ content of $1.08 \%$.

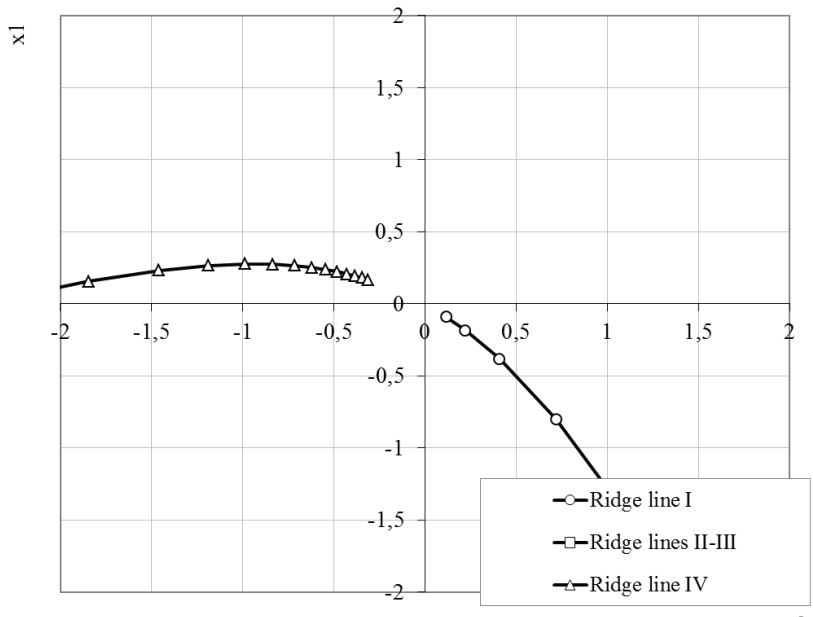

Fig. 3. The set of suboptimal values of input variables for the mathematical model (1)

6.2. Results of investigation of response surfaces describing the mathematical model of the effect of temperature and $\mathrm{BeO}$ content in composite materials on the ultimate strength. Fig. 4 shows the graph of the dependence $r(\lambda)$ for the range of eigenvalues $[-30 ; 30]$, and in Fig. 5 dependence of the output variable on the radius of the cylinder introduced to find the boundary conditions and determine the position of the optimal point with the coordinates $\left(x_{1}^{*}, x_{2}^{*}\right)$ on the indicated boundary of the factor space.

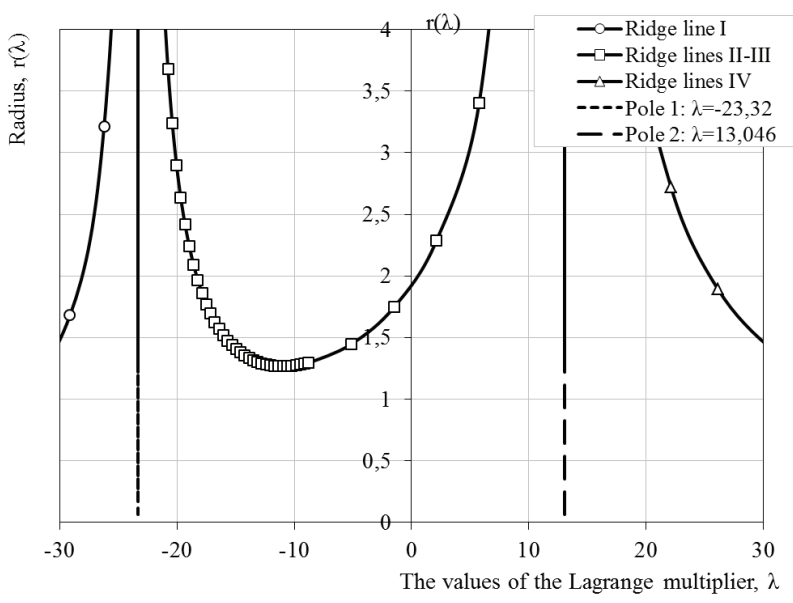

Fig. 4. The graph of the dependence $r(\lambda)$ for the range of eigenvalues $[-30 ; 30]$ 


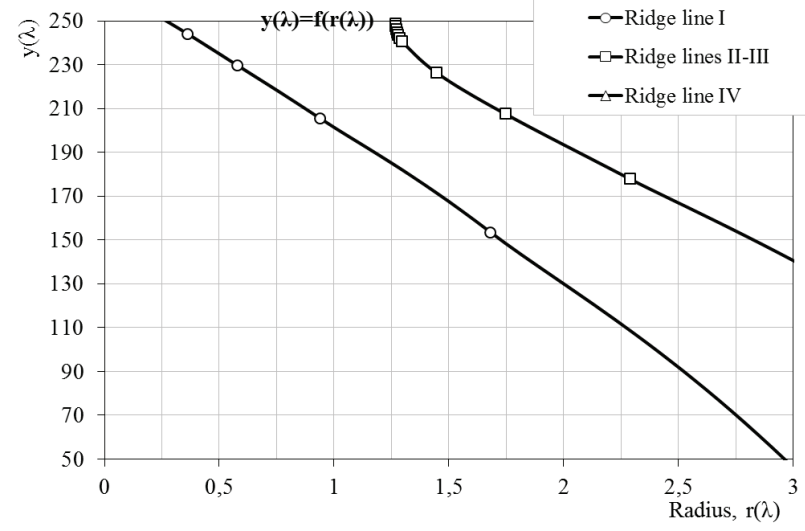

Fig. 5. Dependence of the output variable $y_{1}{ }^{*}(\lambda)$ for the range limited by the selected experiment plan

The solution of the equation $|A-\lambda I=0|$ gives two values of the eigenvalues $\lambda$ in the range $-\infty<\lambda<+\infty$, ensuring the optimal values of the output variable, namely: $\lambda_{1}=-23.32$, $\lambda_{2}=13.046$ (Fig. 4). This means that in the considered range only solutions relevant to the ridge lines I and II, III are meaningful. Investigation of the character of the function $y^{*}(\lambda)$ in the two ranges of the input variable that have meaning in the given problem, located to the left of $\lambda_{1}$ and $\lambda_{2}$, and in the middle between them, makes it possible to find the optimal values of the output variable and the values of the input variables at the boundary of investigated planning area.

Fig. 5 shows that the optimum values of the ultimate strength are achieved in the range from 180 to $250 \mathrm{MPa}$. After analyzing Fig. 6, it is possible to obtain a set of suboptimal values of the input variables providing the optimal values of the ultimate strength.

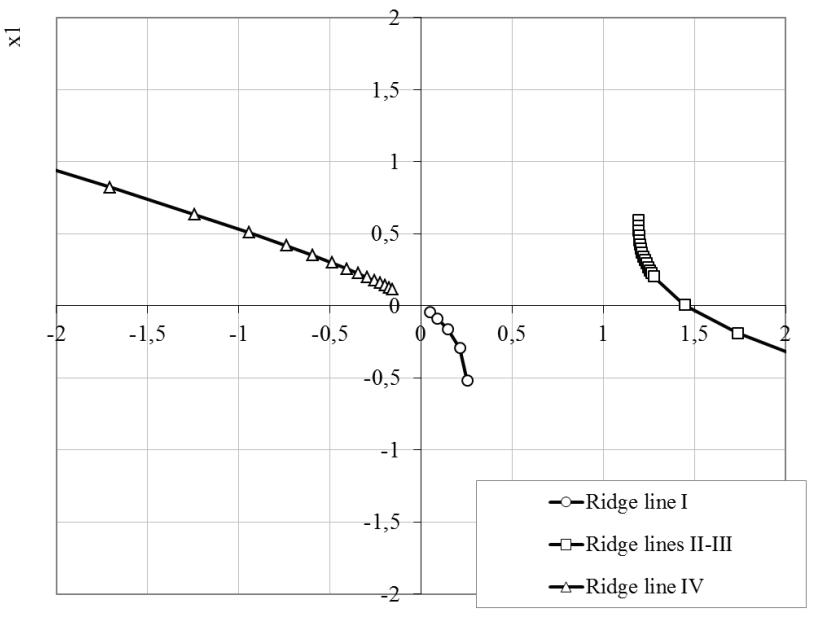

Fig. 6. The set of suboptimal values of input variables for the mathematical model (2)

For example, such values are: $t=384^{\circ} \mathrm{C}$ with $\mathrm{BeO}$ content of $1.35 \%$ and $t=326{ }^{\circ} \mathrm{C}$ with $\mathrm{BeO}$ content of $1.845 \%$.

\section{SWOT analysis of research results}

Strengths. The strength of this research is that the obtained results allow to select the optimal performance characteristics of beryllium-based DSCM, which will en- sure its maximum efficiency and at the same time reduce operating costs, which is economically advantageous. The application of this method of analysis allows to select the optimal values of the incoming variables (temperature and $\mathrm{BeO}$ content), which will ensure the optimal values of the ultimate strength and yield strength.

Weaknesses. The weak side of this research is the restrictions imposed in the process of data analysis, which does not allow to reveal absolutely all the optimal values.

Opportunities. The opportunities of this research are expansion of data analysis range, which will allow to identify a greater number of optimal values of the incoming variables and to expand the parameters of their variation during the manufacturing, operation and disposal of materials.

Threats. The threats of this research are associated with the risk of implementing the research results without conducting appropriate tests that would help identify possible inaccuracies in the model.

\section{Conclusions}

1. Ridge analysis of the response surfaces describing the effect of temperature and $\mathrm{BeO}$ content in composite materials on the yield strength and ultimate strength of the DSCM allows to select the values of the input variables (temperature and $\mathrm{BeO}$ content), which allow obtaining optimal values of the ultimate strength and yield stress. On the basis of this, it is concluded that it is possible to use the solutions obtained in the technological processes for the manufacture, operation and disposal of the beryllium-based DSCM.

2. Thus, it is found that the optimum values of the yield strength, corresponding to a range of values from 130 to $200 \mathrm{MPa}$, are achieved at $t=456{ }^{\circ} \mathrm{C}$ and $\mathrm{BeO}$ content of $1.35 \%$, as well as $t=528^{\circ} \mathrm{C}$ and $\mathrm{BeO}$ content of $1.08 \%$.

The optimum values of the ultimate strength, corresponding to a range of values from 180 to $250 \mathrm{MPa}$ are achieved at $t=384^{\circ} \mathrm{C}$ and $\mathrm{BeO}$ content of $1.35 \%$, as well as $t=326^{\circ} \mathrm{C}$ and $\mathrm{BeO}$ content of $1.845 \%$.

\section{References}

1. Brautman, L. J. Composite Materials [Text] / L. J. Brautman, R. H. Krock. - New York: Academic Press, 1975.

2. Fridliander, I. N. Al-Be splavy metallicheskie kompozitsionnye materialy shirokogo naznacheniia [Electronic resource] / I. N. Fridliander, A. G. Bratuhin, P. Z. Gorbunov, V. V. Gal', K. P. Iatsenko, A. N. Fokanov // Metallovedenie i termicheskaia obrabotka metallov. - 1996. - № 9. - Available at: \www/ URL: http://viam.ru/public/files/1996/1996-202052.pdf

3. Mouritz, A. Aluminium alloys for aircraft structures [Text] A. Mouritz // Introduction to Aerospace Materials. - 2012. P. 173-201. doi:10.1533/9780857095152.173

4. Oz, T. Impact of beryllium additions on thermal and mechanical properties of conventionally solidified and meltspun $\mathrm{Al}-$ 4.5 wt. $\% \mathrm{Mn}-x$ wt. \% Be $(x=0,1,3,5)$ alloys [Text] T. Oz, E. Karakose, M. Keskin // Materials \& Design. 2013. - Vol. 50. - P. 399-412. doi:10.1016/j.matdes.2013.03.024

5. Chen, H. Thermal conductivity of polymer-based composites: Fundamentals and applications [Text] / H. Chen, V. V. Ginzburg, J. Yang, Y. Yang, W. Liu, Y. Huang, L. Du, B. Chen // Progress in Polymer Science. - 2016. - Vol. 59. - P. 41-85. doi:10.1016/j.progpolymsci.2016.03.001

6. Biron, M. Composites [Text] / M. Biron // Thermosets and Composites. - 2013. - P. 299-473. doi:10.1016/b978-1-45573124-4.00006-7

7. Kovaleva, A. V. Kompozitsionnye materialy v tekhnike i issledovanie vozmozhnostei polucheniia izdelii iz raznorodnykh materialov v liteinom proizvodstve [Text] / A. V. Kovaleva, A. A. Chernyi. - Penza: Penzenskii gosudarstvennyi universitet, 2008. - $161 \mathrm{p}$. 
8. Baron, C. Properties of particle phases for metal-matrix-composite design [Text] / C. Baron, H. Springer // Data in Brief. 2017. - Vol. 12. - P. 692-708. doi:10.1016/j.dib.2017.04.038

9. Santos, A. M. C. Characterisation of a real-time fibre-coupled beryllium oxide $(\mathrm{BeO})$ luminescence dosimeter in X-ray beams [Text] / A. M. C. Santos, M. Mohammadi, J. Asp, T. M. Monro, V. S. Afshar // Radiation Measurements. - 2013. - Vol. 53-54. P. 1-7. doi:10.1016/j.radmeas.2013.03.003

10. Yuan, P.-F. High-pressure meta-stable phase of BeO: A first principle study [Text] / P.-F. Yuan, J. Xu, F.-O. Jing // Materials Chemistry and Physics. - 2010. - Vol. 124, № 1. P. 768-772. doi:10.1016/j.matchemphys.2010.07.056

11. Fathalian, A. Optical properties of BeO nanotubes: Ab initio study [Text] / A. Fathalian, R. Moradian, M. Shahrokhi // Solid State Communications. - 2013. - Vol. 156. - P. 1-7. doi:10.1016/j.ssc.2012.11.017

12. Malakkal, L. Thermal conductivity of wurtzite and zinc blende cubic phases of $\mathrm{BeO}$ from ab initio calculations [Text] / L. Malakkal, B. Szpunar, R. K. Siripurapu, J. C. Zuniga, J. A. Szpunar // Solid State Sciences. - 2017. - Vol. 65. - P. 79-87 doi:10.1016/j.solidstatesciences.2017.01.005

13. $\mathrm{Yu}, \mathrm{B} .-\mathrm{R}$. Phase transition and elastic properties of $\mathrm{BeO}$ under pressure from first-principles calculations [Text] / B.-R. Yu, J.-W. Yang, H.-Z. Guo, G.-F. Ji, X.-R. Chen // Physica B: Condensed Matter. - 2009. - Vol. 404, № 14-15. - P. 1940-1946. doi:10.1016/j.physb.2009.03.015

14. Jahn, A. The BeOmax system - Dosimetry using OSL of BeO for several applications [Text] / A. Jahn, M. Sommer, W. Ullrich, M. Wickert, J. Henniger // Radiation Measurements. - 2013. Vol. 56. - P. 324-327. doi:10.1016/j.radmeas.2013.01.069

15. Groppo, D. P. Luminescent response from $\mathrm{BeO}$ exposed to alpha, beta and X radiations [Text] / D. P. Groppo, L. V. E. Caldas // Radiation Measurements. - 2014. - Vol. 71. - P. 81-85. doi:10.1016/j.radmeas.2014.07.009

16. Wang, B. Activation treatment effects on characteristics of $\mathrm{BeO}$ layer and secondary electron emission properties of an activated $\mathrm{Cu}-\mathrm{Be}$ alloy [Text] / B. Wang, E. Wu, Y. Wang, L. Xiong, S. Liu // Applied Surface Science. - 2015. - Vol. 355. P. 19-25. doi:10.1016/j.apsusc.2015.06.189

17. Nieto, J. A. Determination of the kinetic parameters of BeO using isothermal decay method [Text] / J. A. Nieto, C. A. Vega, T. R. Montalvo, E. T. Cabrera // Applied Radiation and Isotopes. 2016. - Vol. 108. - P. 8-11. doi:10.1016/j.apradiso.2015.11.061

18. Makarenko, D. M. Quality management of dispersion-strengthened beryllium-based composite alloy [Text] / D. M. Makarenko // ScienceRise. - 2016. - Vol. 5, № 2 (22). - P. 29-34. doi:10.15587/2313-8416.2016.69259
19. Mohanad, M. K. Modeling of the case depth and surface hardness of steel during ion nitriding [Text] / M. K. Mohanad, V. Kostyk, D. Domin, K. Kostyk // Eastern-European Journal of Enterprise Technologies. - 2016. - Vol. 2, № 5 (80). P. 45-49. doi:10.15587/1729-4061.2016.65454

20. Demin, D. Adaptive modeling in problems of optimal control search termovremennoy cast iron [Text] / D. Demin // Eastern-European Journal of Enterprise Technologies. - 2013. № 6/4 (66). - P. 31-37. - Available at: \www/URL: http:// journals.uran.ua/eejet/article/view/19453/17110

21. Sira, O. Otsenivanie parametrov uravneniia regressii v usloviiakh maloi vyborki [Text] / O. Sira, D. Demin // Eastern-European Journal of Enterprise Technologies. - 2009. - № 6/4 (42). P. $14-19$

22. Raskin, L. G. Iskusstvennaia ortogonalizatsiia passivnogo eksperimenta v usloviiakh maloi vyborki nechetkikh dannykh [Text] L. G. Raskin, D. Demin // Informacijno-kerujuchi systemy na zaliznychnomu transporti. - 2010. - Vol. 1, № 80. - P. 20-23.

\section{ИССЛЕДОВАНИЕ ПОВЕРХНОСТЕЙ ОТКЛИКА, ОПИСЫВАЮЩИХ МАТЕМАТИЧЕСКУЮ МОДЕЛЬ ВЛИЯНИЯ ТЕМПЕРАТУРЫ И СОДЕРЖАНИЯ ВЕО В КОМПОЗИЦИОННЫХ МАТЕРИАЛАХ НА ЛРЕДЕЛЫ ТЕКУЧЕСТИ И ПРОЧНОСТИ}

Методом ридж-анализа проведено исследование поверхностей отклика, описывающих математические модели влияния температуры и содержания $\mathrm{BeO}$ на границы прочности и текучести композиционных материалов, используемых, в частности, при производстве авиационной техники. Показано, что на основе математической модели, построенной путем реализации центрального ортогонального композиционного плана (ОЦКП) второго порядка, могут быть найдены субоптимальные значения технологических режимов. Эти режимы обеспечивают получение оптимальных значений границ текучести и прочности композиционного сплава на основе бериллия с учетом ограничений, налагаемых на технологический процесс.

Ключевые слова: ридж-анализ, субоптимальные значения, композиционный материал, оксид бериллия, предел текучести, предел прочности, поверхность отклика

Makarenko Dmytro, Senior Lecturer, Department of Chemistry, Ecology and Expertise Technologies, Zhukovsky National Aerospace University «Kharkiv Aviation Institute», Ukraine, e-mail: d.makarenko@khai.edu,ORCID:http://orcid.org/0000-0002-4672-2880

\section{Kotok V., Kovalenko V., Solovov V., Yurlova 0.}

\section{THE DETERMINATION OF ELECTROLYTE STABILITY AND CONDITIONS FOR ELECTROCHROMIC $\mathrm{WO}_{3}$ FILMS DEPOSITION}

Для осадження електрохромних плівок $\mathrm{WO}_{3}$ запропоновано гальваностатичний режим: $i_{c}=-0.2 \mathrm{мA} / \mathrm{cm}^{2}, 30$ хв. Плівки, отримані у таких умовах прозорі, якісні та мають гарну адгезію до основи. Показано, що використовуваний електроліт нестабільний та з часом змінює свої властивості. Для відновлення електроліту запропоновано додавати перекис водню згідно з рецептурою.

Ключові слова: оксид вольфраму, осадження електрохромних плівок, пероксовольфрамова кислота, вікно потенціалів.

\section{Introduction}

Electrochromic devices are a class of devices that under applied current are able to change their optical properties: glossiness, color, transparency. The electrochromic devices can usually be in few optical states: uncolored, colored and partially colored. Optical properties of electrochromic devices can be controlled by applying electrical current of different 